\title{
The Use of One Tambon One Product Model as the Strategy to Improve Competitive Advantage and Market Access of Micro, Small \& Medium Enterprises in Effort to Attain Better Development in Welcoming ASEAN Market in Great Malang
}

\section{Gunarianto}

Faculty of Economic, University of Widya Gama Malang, Jl. Borobudur No.35, Blimbing, Malang City, East Java, 65141, Indonesia.

Correspondence Author: Gunarianto, Faculty of Economic, University of Widya Gama Malang, J1. Borobudur No.35, Blimbing, Malang City, East Java, 65141, Indonesia.

Received date: 12 June 2018, Accepted date: 4 September 2018, Online date: 13 September 2018

Copyright: (C) 2018 Gunarianto, This is an open-access article distributed under the terms of the Creative Commons Attribution License, which permits unrestricted use, distribution, and reproduction in any medium, provided the original author and source are credited.

\begin{abstract}
Local leading products supported by local government would have competitive advantage and market access, and also are potentially manageable for better development. These products are optimized through a mechanism called One Tambon One Product in the context of sector-based development, and this optimizationis aimed for several goals, such as: to make sure that these products are potentially marketable at local or global levels, to improve the quality and added-value of these products, and to increase market access to these products. Long-term objective of this research is to formulate One Tambon One Product concept for Micro, Small and Medium Enterprises (MSME) in all regions of Malang Raya. The more specific objectives are: (1) to identify the leading sector or commodity that has the largest contribution to the economic growth of Malang Raya; and (2) to find out One Tambon One Product model that is suitable for the development of MSMEs in Malang Raya. The latter objectives are proceeded as pilot project with monitoring and evaluation to obtain more comprehensive model. The object of this research is Micro, Small \& Medium Enterprises (MSME) in Malang City, Malang Regency, and Batu City. Few methods are used for data analysis, such as: the determination of long list of leading commodities; Analytical Hierarchy Process (AHP) that comprises three stages, which are building hierarchy, conducting survey, and analyzing survey result; value chain analysis used as the approach to understand the result of survey; and the verification on the result of survey with expert discussion, or commonly known as Focus Group Discussion. Result of research indicates that the leading commodity in Malang City includes vegetables, fishes and kinds (wet market), big scale trading (wholesaler), and mixed trading (garments, electronics and others). Leading commodity in Malang Regency comprises of some industries such as food industry, wood industry, metal industry, and plait/pottery/ceramic handicrats. Batu City's leading commodity is represented by wholesaler, star and jasmine hotels, natural and artificial tourisms, food \& beverage industry, wet market, and mixed trading. The implication of this research is that the frame underlying One Tambon One Product model contains with many aspects. One aspect concerns with the establishment of agencies to support business development, including technical support agencies or coordination forum agencies at district, regency/city, and province levels. Other aspect is the founding of cross-institution committee, but it is only built in province level. All of them represent the strategies to improve competitive advantage and market access of MSMEs in Malang Raya to attain better development for them.
\end{abstract}

Key words: One Tambon One Product, Leading Commodity, Competitive Advantage

\section{INTRODUCTION}

Every region has different strategies to develop their Micro, Small, and Medium Enterprises (MSME) to create economic growth at their own place. The development of these MSMEs is always begun with recognizing economical, social, and physical attributes of the region, and also the degree of interaction of the region with others. It is not surprising if the strategies suitable to MSMEs development at certain region may not prevail for all regions or all economic development plans. To develop the potentials of certain region to compete into global market, thus, One Tambon One Product concept is introduced and the use of it must be matched with local competencies because through this concept, the leading sector or product in certain MSMEs can then be selected to be the producer of global class products.

Some criteria must be fulfilled in determining the location for the use of One Tambon One Product model to MSMEs, especially which aims at making them into those with competitive advantage at national and global markets. These criteria are that the location must have diversity of businesses, have clearly defined space order, and have adequate infrastructures for business. One Tambon One Product consists of three principles that must be applied by regions if they want to develop their local leading products. These principles are: (1) thinking globally and being active locally; (2) be self-supported with initiative and creativity; and (3) conducting human resource development.

If a region has a leading sector or product, and been supported by local government, then this region shall have not only competitive advantages but also potentials to develop better. Micro, Small \& Medium Enterprises (MSMEs) are the backbone to regional development, and One Tambon One Product is a concept that must be applied by these enterprises to help them achieving better development. Also, One Tambon One Product is a concept that aids these enterprises to explore and exploit their own resource potentials to promote local-based innovative and creative products with higher added-values and most importantly, environmentally friendly. If a region is able to create a sector or a product with high competency level, then local government only provides necessary supports such as providing the markets, helping the capitalization, and giving other aids concerning with technical and managerial issues. One Tambon One Product is a model for not only developing MSMEs but also improving people welfare. 
Citation: Gunarianto., The Use of One Tambon One Product Model as the Strategy to Improve Competitive Advantage and Market Access of Micro, Small \& Medium Enterprises in Effort to Attain Better Development in Welcoming ASEAN Market in Great Malang. Australian Journal of Basic and Applied Sciences, 12(9): 98-106. DOI: 10.22587/ajbas.2018.12.9.17

The development of local leading sector or product through One Tambon One Product has several goals, such as to develop local leading products into those with marketing potentials at local and global levels, and also to improve quality and added-value of these products to increase their competitive advantage. Any activities related with One Tambon One Product are handled by the Ministry of Cooperative and MSMEs, and this ministry is also the actor with responsibility to promote and apply One Tambon One Product concept for the increase of people incomes.

Result of previous review indicates that there are actually few MSMEs in Malang Raya. These MSMEs have grown into business centers without intervention from local government. Such MSMEs include Leather Handicraft MSMEs in Malang Regency, Soy Cake MSMEs in Malang City, and The Centers of Processed Cassava Products in Batu City. The development of MSMEs in Malang Raya differs from that of MSMEs in other cities. Most of them are not run by professional management, and as a result, they lack of transparent accounting, they have low competitive advantage, and they only do business for livelihood.

The objectives of this research are aimed (1) to identify the leading sector or commodity that will give the largest contribution to the economic growth of Malang Raya; and (2) to find out One Tambon One Product model that is suitable for the development of MSMEs in Malang Raya by putting this model as the pilot project with monitoring and evaluation to obtain more comprehensive model.

This research is a comprehensive follow-up based on reviews given by previous studies. Reviews about MSMEs for poverty eradication and MSMEs' competitive advantages were already conducted by Tuti Hastuti et.al., (2007), Tuti Hastuti et.al.,(2008), Gunarianto et.al., (2008), Gunarianto and Nasri (2011) and Tuti Hastuti et.al., (2013,2014),Mulyono(2015,2016) and Gunarianto et.al., (2017).

\section{Review of Literatures:}

There are three basic principles of One Tambon One Product applied to commodities. These are explained as follows: (1) The commodities are produced from local resources but with global competitive advantages (locally originated but globally competitive); (2) The commodities enforce the sustainability of innovation and creativity; and (3) The commodities are emphasized on human resource development. According to Sri Hermuningsih Dewi Kusumaand Wardani (2012), for implementing these principles, many approaches are used, such as:

a) Cluster-based (Top-Down);

b) Local Core Competence (Bottom-Up);

c) One Village One Product/ OVOP;

d) Supporter-based;

e) Collaboration between Central Government, Local Government, Private, and Local Community;

f) The utilization of knowledge, workers, and other local resources with local distinction;

g) Quality improvement and product appearance;

h) Good promotion and marketing at national and global levels;

i) The use of OVOP to deliver extension for Small-Medium Industries (SMI), especially for those at SMI centers with the best products.

Empirical review about local core competencies has been carried out by Gunarianto dan Nasri (2011) in Pasuruan City. It was found that competitive advantage is the accumulation of capabilities and cooperations achieved by MSMEs in processing various sources owned by certain groups or organizations in order to produce the products with favorable quality. Going toward better development is not a merely political decision, but also an effort involving supports of all stakeholders such as local government, DPRD, related agencies, business entities, cooperative and association, and colleges.

Critical review given by Saputro et.al.,(2010) has mentioned that main issues dealt by Micro, Small \& Medium Enterprises (MSMEs) are limited resources, lack of financial support, business process that mostly are still conducted manually, still very few MSMEs that can implement computer program applications for optimizing the operationals, and most of MSMEs' operationals are not integrated. Therefore, computer program applications are possibly needed to support MSMEs to cope with global competition. Further study by Tuti Hastuti et.al., (2013) on the empowerment of MSMEs in Malang Raya has found the mostsuitable model to deal with problems challenging MSMEs in Malang Raya is by providing consultation and training, and followed by enlisting supports from all actors related directly to the empowerment of MSMEs in Malang Raya. There are at least 5 (five) development programs that can be arranged for the progress of MSMEs, and these include: (i) human resource development program; (ii) MSMEs' development program; (iii) self-supported fertilization program; (iv) business development program; and (v) precise information supply program.

Sajarwan et.al., (2009) explained that based on time perspective, the developmental policy of one village one product(OVOP) has been recommended for in Palangkaraya City as the base policy that would be used to provide directions for middle-term and long-term policies. Middle-term policies planned may include: improving quality and quantity of old products before sending them to new markets; creating new products for old markets; and doing follow-up actions for the programs previously made by government, either sectoral or regional programs, including those related with fostering, consultation, extension, and other community services.

Ratmono et.al.,(2016) has conducted a study in Lampung Province with title "One Village One Product(OVOP) as an Approach to the Regional Leading Product Development Program". Their finding was that OVOP is top-down approach, and therefore, OVOP must be promoted with understandable words to keep the community comprehends spirits inside it. Central actors in the community play very important role in disseminating OVOP, and they make OVOP usage to be more effective to develop the leading products currently owned by the city regions in Lampung Province.

Adirestuty et.al.,(2011) discovered that still many Micro, Small \& Medium Enterprises (MSMEs) do not have reliable capability to create competitive products for global markets. Pasaribu et.al.,(2011) elaborated that OVOP approach is people initiation to rely on their self-support in managing their economic business by utilizing locally provided resources. OVOP approach includes some activities such as: (a) to decide the products that need to be developed; (b) to identify development potentials of these products and the related problems; (c) to give fostering about the use of processing technology, the improvement of quality, the enhancement of marketing scope, and the increase of human resource capacity; and (d) the implementation of monitoring and evaluation for business improvement. For instance, rural economic activity shall be more accurately planned, and the implementation of this activity must be directed to improve income and welfare of economic actors by using the available database.

Triharini et.al.,(2012) have investigated the use of OVOP in Purwakarta, the region known by its potentials of ornamental pottery and ceramic handicrafts. The use of OVOP is evaluated and it is recommended that the consistent action of government and the participation of people are truly needed to ensure the successful implementation of government programs. Moreover, the success of the programs is also determined by the design of handicraft products. Indeed, the role of designers is very important to this matter, especially when they can develop designs that can understand market demand, conserve traditional handicraft values, and solve the problems faced by MSMEs.

Nurcahyo et.al., (2012) discussed about local core competencies of Bekasi Regency and attempted to identify competencies that help the regency to attain its development. Result of their study indicates that the best core competency is that giving the biggest Gross Regional Domestic Product, which also means that this competency has the greatest contribution to the economic activity in Bekasi Regency. Food \& beverage MSMEs (industry) has been the most potential industry on some variables of core competency, such as marketing, environmental supporting capacity, social impact, industrial organization, production technology capacity, and local development contribution.

Furthermore, critical review Arsoowan Laeha (2013) has shown that the implementation of One Tambon One Product policy in Tambun Natam, Yala Province, Thailand, is determined not only by factors of implementation technique such as resources, communication, bureaucratic structure, and disposition, as indicated by policy implementation theory/model from Western. Other factors also influence the final results, such as environment and socioeconomic status. This review found that two factors have affected the implementation of One Tambon One Product, and these are the supporting factors such as resource support level, communication, disposition, and bureaucratic structure, and also the constraining factors such as resource limit and communication.

Method of Research:

The use of One Tambon One Product for MSMEs at certain locality is determined through an analytic stages. In general, the analytic frame is shown in the following figure.

This research was conducted in Malang City, Batu City, and Malang Regency using the population of Micro, Small \& Medium Enterprises (MSMEs). 
Citation: Gunarianto., The Use of One Tambon One Product Model as the Strategy to Improve Competitive Advantage and Market Access of Micro, Small \& Medium Enterprises in Effort to Attain Better Development in Welcoming ASEAN Market in Great Malang. Australian Journal of Basic and Applied Sciences, 12(9): 98-106. DOI: 10.22587/ajbas.2018.12.9.17

Sample was determined by cluster sampling. This technique was used by some considerations:

1. Clustered MSMEs (sample) remain with certain centers and have same business pattern.

2. Clustered MSMEs have good survivability, supporting capacity and competitive advantage against more powerful economic forces.

Data collection method includes field survey, Participatory Research Appraisal (PRA), Focus Group Discussion (FGD) and seminar \& workshop. Data analysis method utilizes survey conducted on MSMEs in each locality. Quantitative and qualitative data concerning quality and quantity of MSMEs are obtained from Department of Industry, Trade and Cooperative of each locality. Primary data are compiled by sending questionnaire to each MSME.

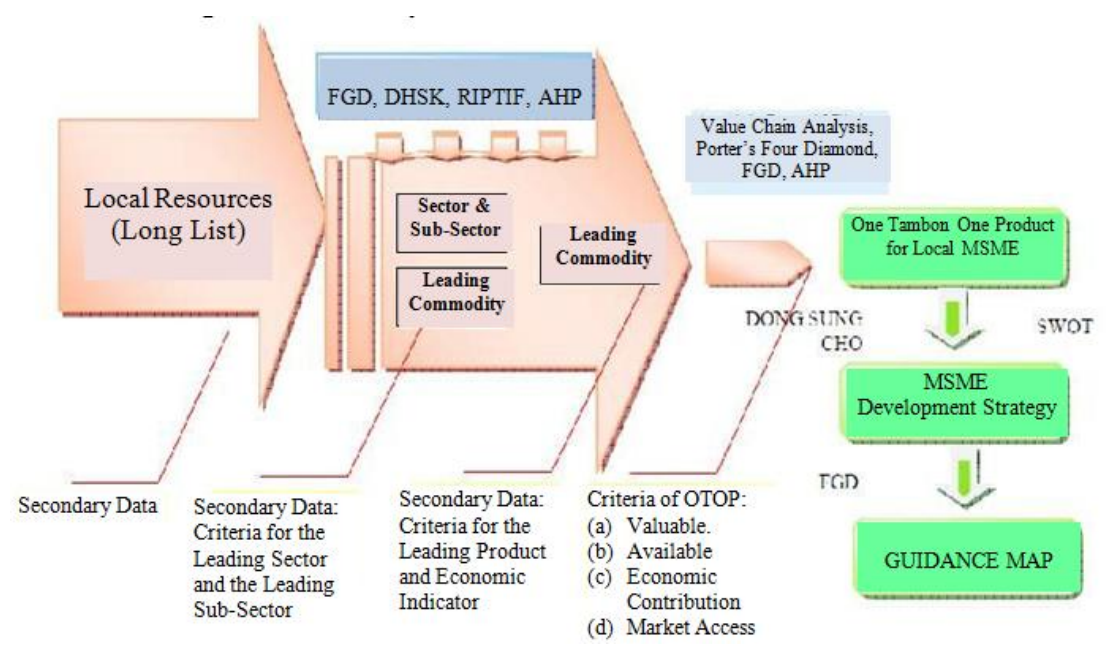

Fig. 1: The Analytical Frame of One Tambon One Product Determination.

\section{Result of Research:}

The determination of leading product that can be developed in Great Malang is preceded by several activities. It begins with analyzing the resources, including natural and human resources. Any potentials, constraints and challenges concerning these resources must be understood.

Infrastructures for the access to Great Malang from Surabaya, the capital of East Java Province, and other regions in the province, shall be made available either from land or air. It is an important consideration because Great Malang is a strategic transit city. The challenge is that the quality and width of the roads must be improved to facilitate industrial transport activities. The construction of the leading product showrooms in strategic paths of Malang Raya is still considered as less. Concerning with human resource, the welfare of people in Malang Raya still depends on the nature. People still respect the nature and only use it for livelihood. This culture contradicts with the plan for improving business performance that always needs huge scale of exploitation. Education institutions want to improve culture and skill of the people, and periodically, sport contest is organized to encourage people to increase their creativity in creating products, foods, and others.

Regarding to added-value aspect, Great Malang has various commodities that potentially deliver derivative products with great added-value. Almost all commodities are sold in the form of half-finished products and the aspect of quality and creativity is considered as less important. This subordinate status is caused by the less availability of technology for further processing. Indeed, the commodity has provided many derivative products but creativity and innovation are impeded by the lacking of high technology despite its abundant stock of raw materials.

If marketing aspect is reviewed, the leading commodities in Great Malang have been prepared to be sold at local and regional markets of Great Malang, and even outside the region. The problem is that the information about market is very limited and it affects entrepreneurs' efforts to increase their productivity for Great Malang market. The products have great varieties and uniqueness, and massive promotion into the regions of Great Malang is needed.

Great Malang image has been generally identified with its name as education city and tourism city. Local image is empowered through its relation with the leading products. All these identities shall attract many investors, buyers and tourists.

Local culture in Great Malang has given this region with the capacity to become leader in the industry, education, trade, and tourism. Kinship level is very good among the peoples. People represent a great potential that must be exploited for Great Malang development. They can make advancing steps and utilize their times in more productive ways.

Based on investor view, the aspect of local reputation as indicated by condition, richness, and location of the nature, it is said that Great Malang has great potential to be developed as the destination of investment. This aspect would deliver the capacity to develop infrastructures to create conducive investment climate.

\section{Economic Development in Great Malang:}

Economic analysis is conducted on gross regional domestic product (PDRB). This analysis exploits secondary data about macro economic condition in Great Malang. There are 17 (seventeen) sectors with great contribution to PDRB, and these sectors represent the living behavior of Great Malang peoples when they exploit the surrounding resources. Among these sectors include Agriculture; Mining and Excavation; Processing Industry; Electricity, Gas and Clean Water; Construction; Trade; Restaurant and Hotel; Transport; Telecommunication; Finance; Rent; Firm Service; and Other Services.

From data processing, it is then understood that the contribution of each leading sector to gross regional domestic product based on the prevailing price (PDRB-ADHB) in Malang City can be illustrated in the following figure.

The figure above explains that Malang City economic structure has been dominated mostly by some sectors such as: Wholesale \& Retail Trading of Car \& Motorcycle and Reparation; Processing Industry; Construction; and Education Service. Economic growth rate of Malang City for period 2013-2016 can be indicated as follows:

In 2013, actual growth rate of Malang City was $6.20 \%$ but this rate decreased in 2016 to $5.61 \%$. It was caused by global crisis prolonged since 2008. Global economic was yet to recover its stability, and Indonesia was impacted by this sway. East Java Province, as a developing province in Indonesia, must experience slowdown on its national and regional growths, and it affects Malang City's economic growth.

Income per capita of Malang City for period 2012-2016 showed positive trend, from IDR 46,429,903 in 2012 to IDR 66,757,279 in 2016. It is described in the following table:

The welfare of people in Malang City was improving with the increase of gross regional domestic product based on the prevailing price.

For Malang Regency, the contribution of each leading sector to gross regional domestic product based on the prevailing price (PDRB-ADHB) is described in the following figure.

The economic structure of Malang Regency is dominated by some leading sectors such as: Processing Industry; Wholesale \& Retail Trading of Car \& Motorcycle and Reparation; Agriculture, Forestry and Fishery; and Construction. Economic growth rate is growth rate of various economic sectors. This rate is also a description of economic fluctuation. Economic growth rate in Malang Regency for period 2013-2016 can be explained as follows:

Economic growth rate of Malang Regency is clearly shown in the table above. In 2013, the rate was 5.30\% and it increased in 2014 to $6.01 \%$. But it declined 
Citation: Gunarianto., The Use of One Tambon One Product Model as the Strategy to Improve Competitive Advantage and Market Access of Micro, Small \& Medium Enterprises in Effort to Attain Better Development in Welcoming ASEAN Market in Great Malang. Australian Journal of Basic and Applied Sciences, 12(9): 98-106. DOI: 10.22587/ajbas.2018.12.9.17

in 2015 to $5.27 \%$ and was relatively increasing in 2016 toward $5.30 \%$.

Malang Regency's income per capita for period 2012-2016 indicates positive trend, precisely from IDR 21,196,068 in 2012 to IDR $31,943,823$ in 2016. This increasing trend is shown in the table as follows:

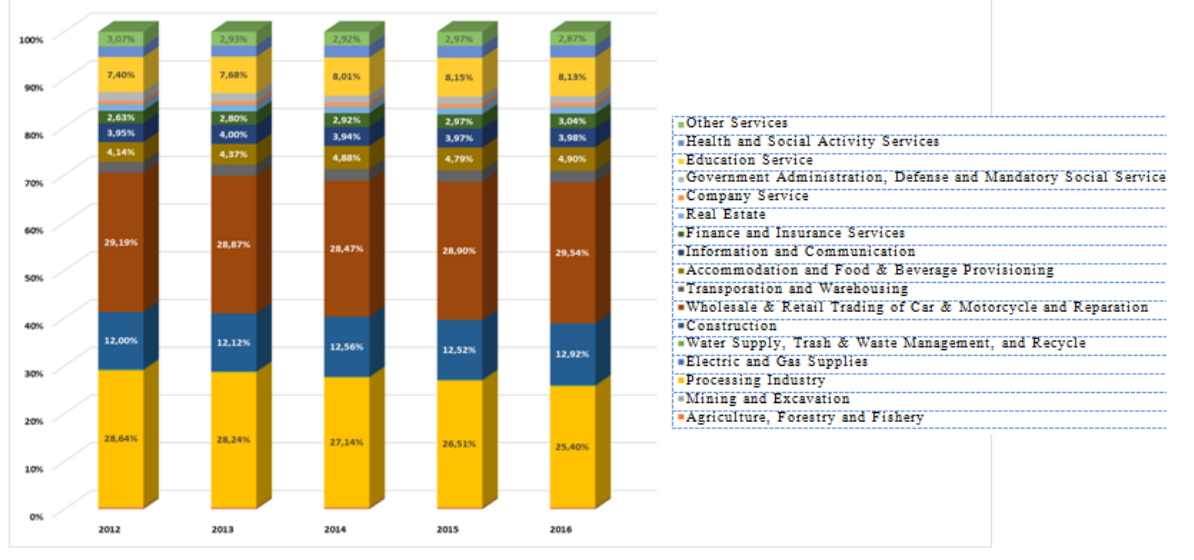

Fig. 2: Description of Economic Structure of Malang City (PDRB-ADHB for Period 2012-2016) Source : Data are processed.

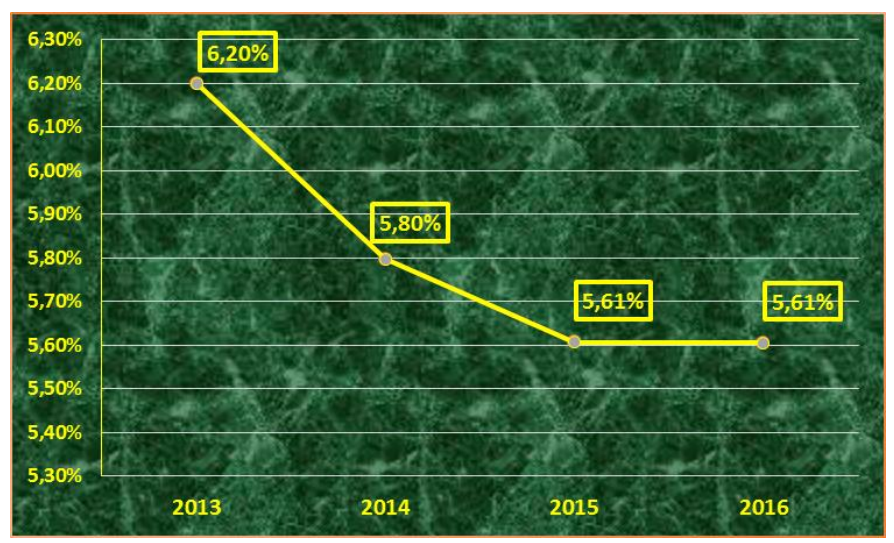

Fig. 3: Economic Growth Rate of Malang City for Period 2013-2016 Source: Data are processed.

Table 1: Income per Capita of Malang City for Period 2012-2016.

\begin{tabular}{|c|c|c|c|}
\hline \multirow{2}{*}{ Year } & PDRB-ADHB & Population Rate & Income per Capita (IDR) \\
\cline { 2 - 4 } & Total (IDR Billions) & 834,527 & $46,429,903$ \\
\hline 2012 & $38,747.0$ & 840,803 & $50,927,351$ \\
\hline 2014 & $42,819.9$ & 85,973 & $55,041,016$ \\
\hline 2015 & $46,563.2$ & $858,876,912$ \\
\hline 2016 & $51,824.4$ & 856,410 & $66,757,279$ \\
\hline
\end{tabular}

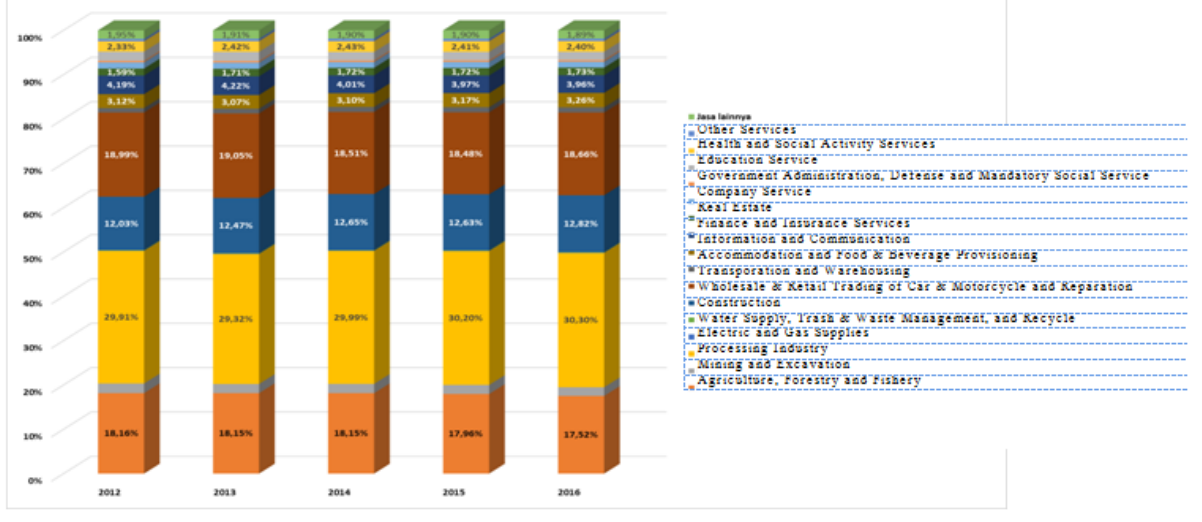

Fig. 4: Description of Economic Structure of Malang Regency (PDRB-ADHB for Period 2012-2016).Source: Data are processed 
Citation: Gunarianto., The Use of One Tambon One Product Model as the Strategy to Improve Competitive Advantage and Market Access of Micro, Small \& Medium Enterprises in Effort to Attain Better Development in Welcoming ASEAN Market in Great Malang. Australian Journal of Basic and Applied Sciences, 12(9): 98-106. DOI: 10.22587/ajbas.2018.12.9.17

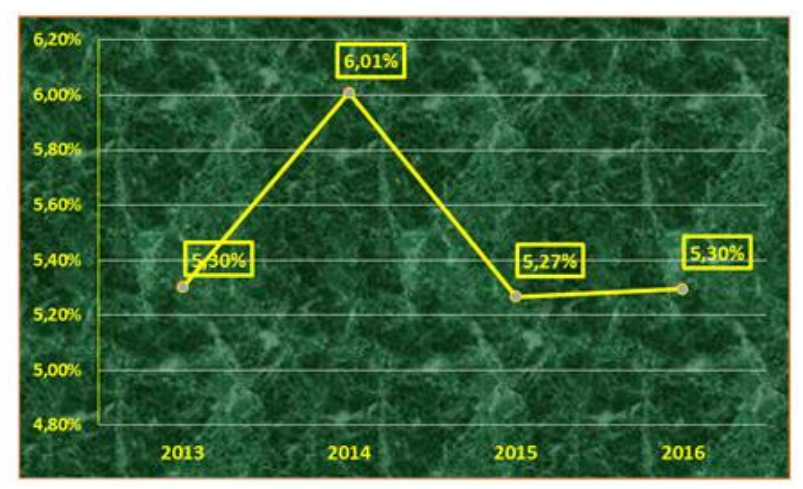

Fig. 5: Economic Growth Rate of Malang Regency for Period 2013-2016.

Table 2: Income per Capita of Malang Regency for Period 2012-2016.

\begin{tabular}{|l|l|l|l|}
\hline Year & PDRB-ADHB & Population Rate & Income per Capita (IDR) \\
\cline { 2 - 4 } & Total (IDR Billions) & $2,490,878$ & $21,196,068$ \\
\hline 2012 & $52,796.0$ & $2,508,698$ & $23,388,523$ \\
\hline 2013 & $58,674.7$ & $2,527,087$ & $26,089,680$ \\
\hline 2015 & $65,930.9$ & $2,544,315$ & $29,022,322$ \\
\hline 2016 & $73,841.9$ & $2,560,675$ & $31,943,823$ \\
\hline
\end{tabular}

Based on this trend, it can be said that the welfare of Malang Regency peoples has been better with the increase of gross regional domestic product based on the prevailing price. figure.

For Batu City, the contribution of each sector to gross regional domestic product based on the prevailing price (PDRB-ADHB) is arranged in the following

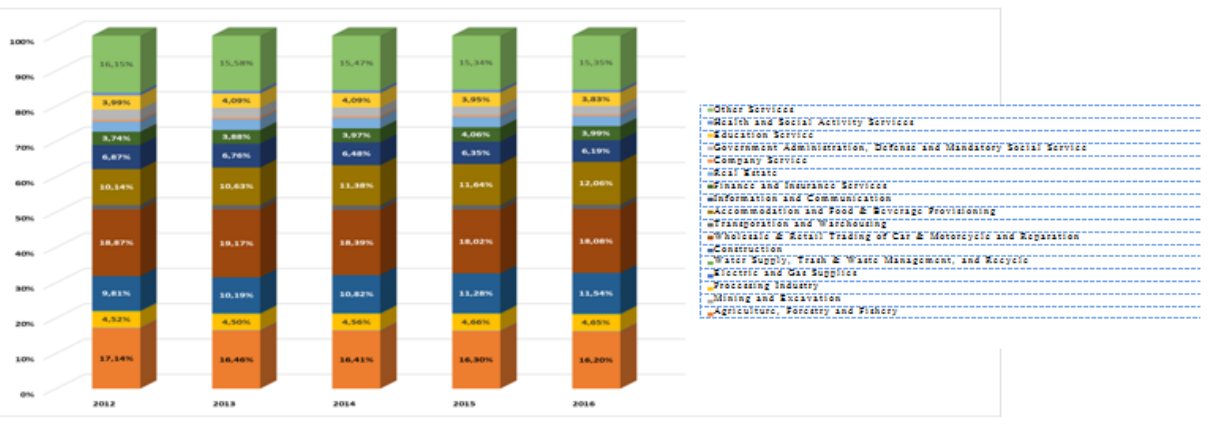

Fig. 6: Description of Economic Structure of Batu City (PDRB-ADHPeriod 2012-2016).

It can be explained from the figure above that Batu City's economic structure is dominated by some leading sectors, such as: Wholesale \& Retail Trading of Car \& Motorcycle and Reparation; Agriculture, Forestry and Fishery; Other Services; Accommodation and Food \& Beverage Provisioning; and Construction. All these sectors experience income increase, which then gives better effect on regional income. Economic growth rate of Batu City for period 2013-2016 is explained as follows:

Table 3: Economic Growth Rate of Batu City for Period 2013-2016.

\begin{tabular}{|l|l|}
\hline Year & Economic Growth Rate \\
\hline 2013 & $7.29 \%$ \\
\hline 2014 & $6.90 \%$ \\
\hline 2015 & $6.69 \%$ \\
\hline 2016 & $6.61 \%$ \\
\hline
\end{tabular}

As indicated by table above, in 2013, actual growth rate of Batu City was 7.29\% but it declined in 2016 to 6.61\%. Income per capita of Batu City is depicted in the following table.

The 2012-2016 income per capita of Batu City indicates positive trend from IDR 41,497,895 in 2012 to IDR 63,770,465 in 2016.

The Determination of One Tambon One Product for Great Malang:

Analytical Hierarchy Process (AHP) is used in this research with the aim to assess measurable and unmeasurable factors and sub-factors that affect the making of decision. The selection of methodology is based on problem characteristic and also on strength and weakness of other methods. Importance level of 
Citation: Gunarianto., The Use of One Tambon One Product Model as the Strategy to Improve Competitive Advantage and Market Access of Micro, Small \& Medium Enterprises in Effort to Attain Better Development in Welcoming ASEAN Market in Great Malang. Australian Journal of Basic and Applied Sciences, 12(9): 98-106. DOI: 10.22587/ajbas.2018.12.9.17

criterion is ensured based on the value of paired criteria. Basically, there are three steps in AHP model, respectively: building hierarchy, conducting survey, and analyzing survey result.

In the step of building hierarchy, there are 3 (three) levels of hierarchy, such as:

a. LevelI: Decision target is placed on top of hierarchy. In this research, the target is "to select the priority scale for the leading commodity in Great Malang".

b. LevelII: Great Malang leading commodity is assessed at district level.

c. LevelIII: Sub-criteria are determined, and in this research, there are 5 (five) sub-criteria for leading commodity, precisely: local content, competitive advantage, local genuine, raw material, added-value, income increase, worker absorption, and environmentally friendly.

Table 4: Income per Capita of Batu City for Period 2012-2016.

\begin{tabular}{|l|l|l|l|}
\hline Year & PDRB-ADHB & Population Rate & Income per Capita (IDR) \\
\cline { 2 - 4 } & Total (IDR Billions) & 197,700 & $41,497,895$ \\
\hline 2012 & $8,079.0$ & 196,189 & $46,274,853$ \\
\hline 2013 & $9,078.7$ & 198,608 & $51,658,086$ \\
\hline 2014 & $10,259.7$ & 200,485 & $57,412,660$ \\
\hline 2016 & $11,510.4$ & 202,319 & $63,770,465$ \\
\hline
\end{tabular}

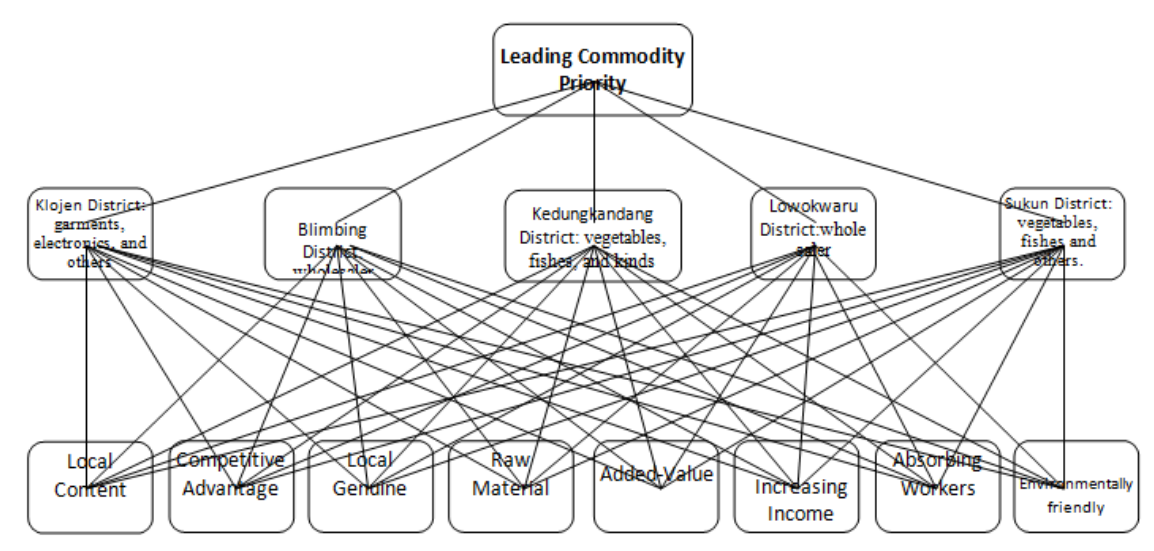

Fig. 7: AHP Hierarchy Structure for Leading Commodity Priority in Malang City.

As shown by AHP Hierarchy Structure, leading commodity in Malang City includes vegetables, fishes and kinds (wet market), big scale trading (wholesaler), and mixed trading (garments, electronics and others).

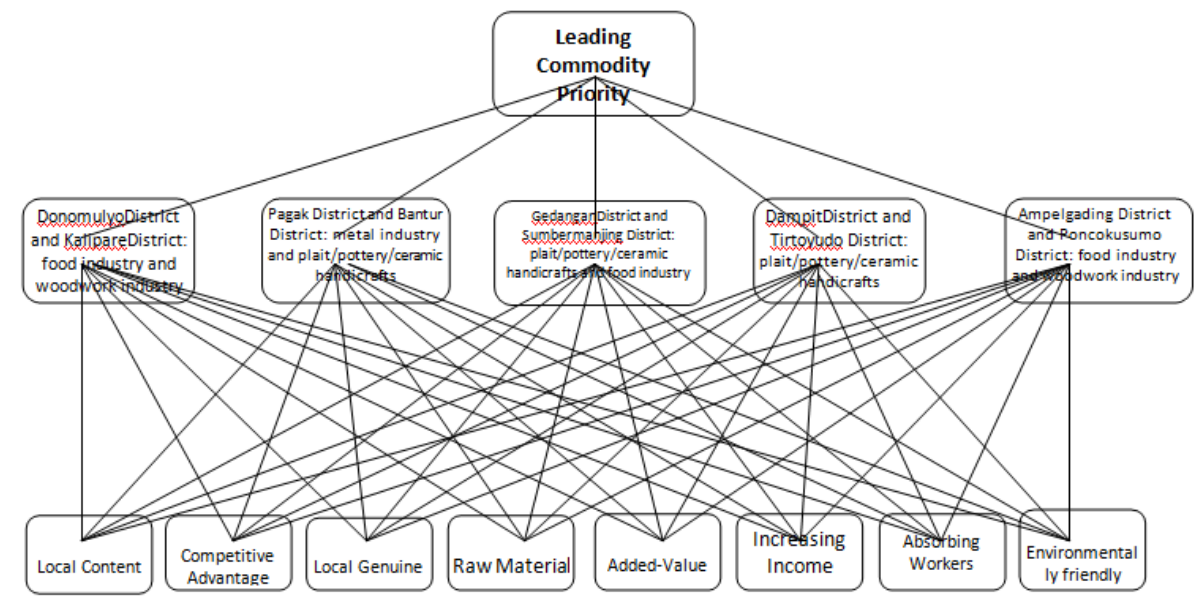

Fig. 8: AHP Hierarchy Structure for Leading Commodity Priority in Malang Regency.

Leading commodity in Malang Regency is dominated by woodwork industry,metal industry,plait/pottery/ceramic handicrafts and food industry.

Leading commodity of Batu City is represented by wholesaler, star hotel, jasmine hotel, natural and artificial tourisms, food \& beverage, wet market, and mixed trading.

Research also conducted value chain analysis. This analysis divides value creation activity into two groups, respectively primary activity and supporting activity. The result of this analysis is enforced by expert discussion (Focus Group Disscusion). After determining what is supposed to be the leading commodity of Great Malang, the next step is to establish development plan. This development plan is initiated with information derived from business environment analysis. By this information, road map and action plan are prepared. To facilitate the process of business environment analysis and also to identify the competitive advantage factors, then Diamond Porter approach is used. Four factors are identified as affecting to competitive advantage. These include: the condition of input (resource) factor; the condition of strategy and business competition; the condition of demand; and the condition of supportive MSMEs. All these factors are related and influencing to each other. 
Citation: Gunarianto., The Use of One Tambon One Product Model as the Strategy to Improve Competitive Advantage and Market Access of Micro, Small \& Medium Enterprises in Effort to Attain Better Development in Welcoming ASEAN Market in Great Malang. Australian Journal of Basic and Applied Sciences, 12(9): 98-106. DOI: 10.22587/ajbas.2018.12.9.17

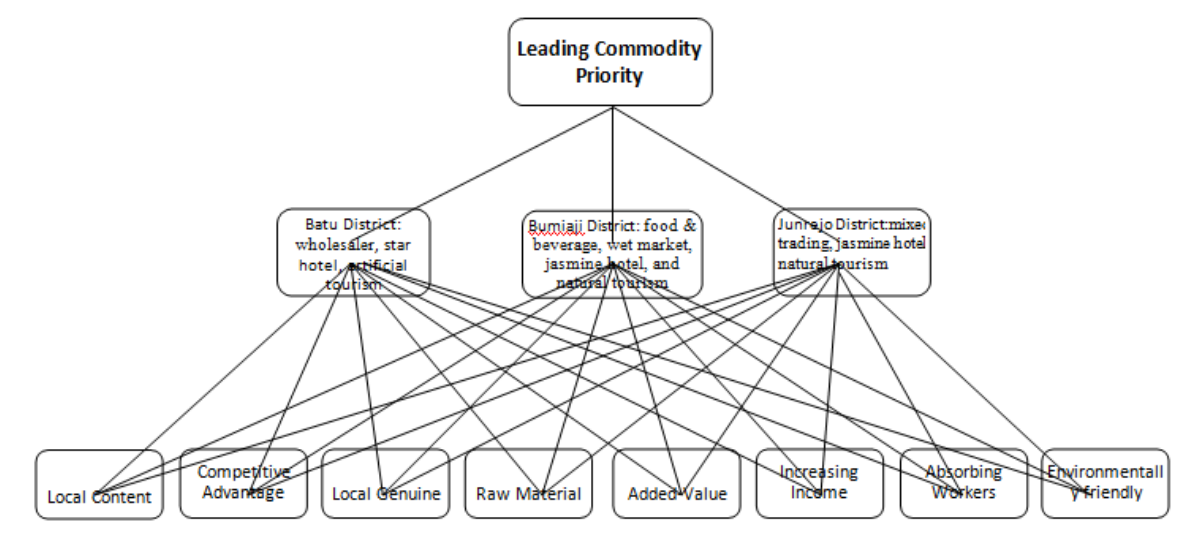

Fig. 9: AHP Hierarchy Structure for Leading Commodity Priority in Batu City.

The condition of resource factor and the condition of supportive MSMEs are greatly affected by government factors that may support (or even constraint) the development of targeted MSMEs. The implementation of strategies to develop targeted MSMEs, therefore, shall need the support of government policy and the conditioning of social environment in order to ensure that business environment is improving. The condition of demand and the condition of supportive MSMEs are affected by business opportunity of the targeted industries. Strategies for developing the targeted MSMEs, therefore, are promoting MSMEs to specific business environment to increase bargaining position of targeted MSMEs in the market and optimizing the capability (or limitation) of the supportive MSMEs through innovation using the existing opportunities. These both activities or strategies must be done in comprehensive way.

Result of analysis indicates that Malang City has potentials to be the supplier of various commodities such as vegetables, fishes and kinds (wet market), big scale trading (wholesaler), and mixed trading (garments, electronics and others). These potentials are supported by the availability of human resource and the presence of financial institutions in Malang City. The constraints are explained in these statements: trading system is still poorly organized; trading is still done from markets or traditional shops that are always less integrated; and trading often proceeds irregularly or also in group. Therefore, training shall be given concerning with trading sytem to equip entrepreneurs with capacity to produce the more organized and integrated trading based on the area where trade is conducted. Local government shall watch over the specific area (centers) that produces homogenous trading commodities. Local government thus must develop synergy with other area to establish distribution channel comprising with traders, industries or MSMEs.

Malang Regency has potentials to be the supplier of various commodities delivered by food industry, woodwork industry, metal industry, and plait/pottery/ceramic handicrafts. Natural and artificial tourims, and also hotel are also the leading commodities for Malang Regency. All these commodities are supported by extensive land width, competent human resource, and local government' supports. These commodities can be empowered through training on business management to keep the participants informed about promotion, price, package, business communication, trademark, competitive advantage, and supplier distribution channel. This training shall be given periodically or at regular schedule.

Batu City is the highland but it has potentials to be the supplier of some commodities, such as vegetables or the kinds sold by wholesaler. This city is very popular with natural and artificial tourims and also greatly identified with the development of hotel as tourist destination center. The producers' productivity and their market can still be optimized recalling the facts that the icon of Batu City as City of Apple is not yet diminishing, and local government to promote this icon is yet to be optimum. Therefore to achieve this goal, local government must cooperate with relevant MSMEs or industries, or seek the supports from financial institutions, or possibly consult with experts to redesign the previous icon into Batu City as City of Tourism.

Local governments in Great Malang, including Malang City, Malang Regency, and Batu City, play important role in using One Tambon One Product as a program to improve of MSMEs' competitive advantage and market access. It helps MSMEs to give added-value to the products through processing (value chain), packaging, network enhancement, quality improvement, and integrated marketing.

Local leading products shall be regionally powerful and globally popular, and to achieve this position, the products must be made on quality and competitive advantage. It can manifest through creating processing industry (value chain) nearby main workplace. Result of analysis found that Great Malang's leading commodity with the biggest contribution to PDRB can be explained as follows: 1) The leading commodity of Malang City is represented by vegetables, fishes and kinds (wet market), big scale trading (wholesaler), and mixed trading (garments, electronics and others); 2) Batu City leading commodity involves: vegetables/wholesaler, natural and artificial tourisms, and hotel development as one of tourist destination; and 3) Malang Regency is identified with commodities from food industry, woodwork industry, metal industry, and plait/pottery/ceramic handicraft.

Leading commodities of each region in Great Malang shall be improved for their quality and also be set into orderly package to increase their economic added-value on the eyes of immediate consumers. Such appearance shall develop these commodities into products with economic excellency and national identity. It definitely aligns with the objective of using One Tambon One Product to improve commodities' marketing potentials at local or international markets (go global). These potentials can be achieved by improving quality and added-value of commodities to ensure their competitive advantage over the imported products.

It is expected that One Tambon One Product will enforce and improve competitive advantage and market access, and therefore, the formulated model is displayed as follows:

The display of skeleton model is very relevant to the decision made during work deliberation held by the Ministry of Cooperative and Small-Medium Enterprises with Fourth Commission in DPR. It was decided that One Tambon One Product shall be applied to other province, and the yard stick of achievement has been determined, which is called "key development milestone with 100 points of One Tamb on One Product". The involved steps for this achievement include: increasing the added-value of leading products by establishing processing industry, supporting the processing structure, improving market access to the products through business meeting or business matching, beautifying the design, clearing up the package, and promoting the products to local, national and international markets. Other ways to this achievement may include: using One Tambon One Product to improve product supply chain; building the capacity of human resource through consultation, extension and training; conducting comparative study; and increasing the participation of local government in effort to improve competitive advantage and market access.

Community-based mentoring can be given for local community in Great Malang region to help them increasing economic potentials of their commodities. Added-value can be increased by establishing processing industry and setting the products into highly competitive package. More extensive economic promotion (concerning with culture, product and natural potentials) for One Tambon One Product-based leading products shall be conducted in national and international scales (through fairs, events, and festival). Such promotion may be facilitated by local governments of Great Malang. Moreover, by One Tambon One Product initiative, it is expected that Great Malang peoples would be self-supported, arised, and creative. Indeed, Great Malang local governments shall encourage human resource to be creative and innovative. It is possibly done by introducing new innovation in agriculture, handicrafts, tourism, services, and product marketing, and also by improving quality, productivity, and competitive advantage.

Result of interview between the author and stakeholders has indicated that the role of government agencies in Great Malang has been supportive already despite challenges and problems unresolved yet. Therefore, strong commitment and participation of all community components are needed, especially during coordination between sectors and actors. People shall be made aware about economic potentials in their immediate region. Financial aids from central and local government must be ensured. Local governments may facilitate this process by providing structures \& infrastructures, institutionalizing One Tambon One Product, building the capacity of business groups, giving technical escort on the field, and others. Department of Cooperative and Small-Medium Enterprises for East Java 
Province also plays some roles such as conducting comparative study with other provinces, arranging business meeting with buyer candidates, and organizing exhibitions. Meanwhile, Department of Cooperative and Small-Medium Enterprises for Malang City or Malang Region may do the roles of building the cooperative; providing information concerning cultivation, packing, design, and marketing techniques; facilitating the deployment of processing technology; and providing structures \& infrastructures to support processing technology. All these roles shall be helpful in improving competitive advantage and market access of the leading commodities from each region in Great Malang.

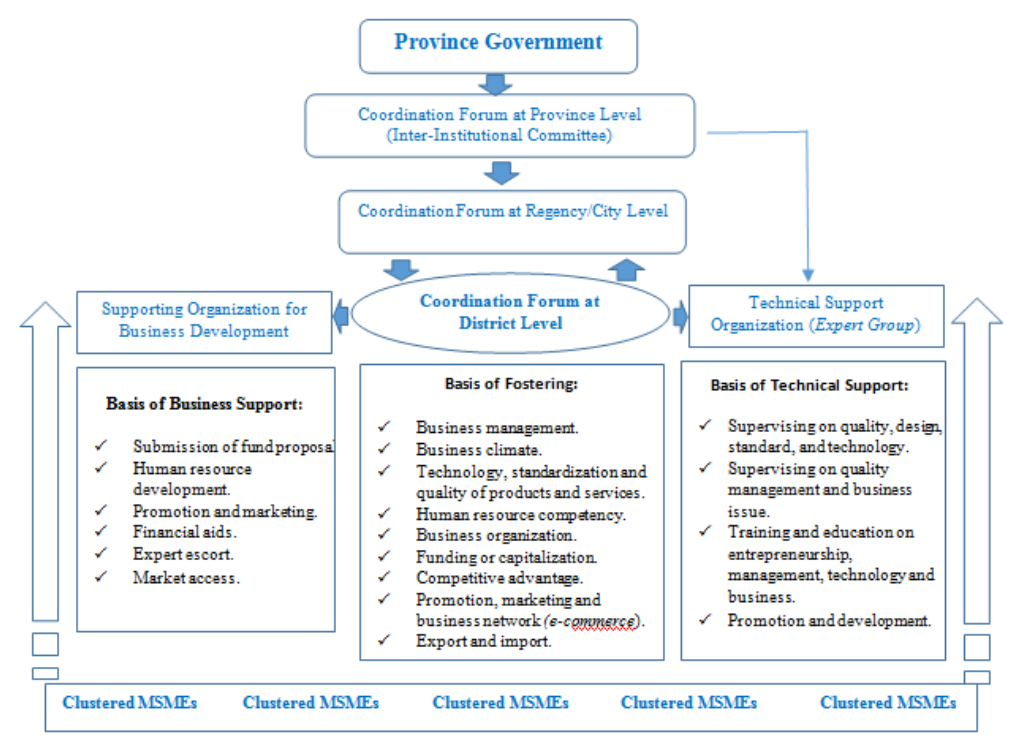

Fig. 10: Skeleton Model of Leading Commodity Empowerment With One Tambon One Productin Great Malang Region.

Conclusion:

Leading commodity in Malang City includes vegetables, fishes and kinds (wet market), big scale trading (wholesaler), and mixed trading (garments, electronics and others). Leading commodity in Malang Regency is represented by some industries such as food industry, wood industry, metal industry, and plait/pottery/ceramic handicrafts. Leading commodity in Batu City is indicated by wholesaler, star and jasmine hotels, natural and artificial tourisms, food \& beverage industry, wet market, and mixed trading.

Great Malang's local governments are already playing significant roles but problems and challenges still exist. What is needed is strong commitment and participation of the community, especially when the government must coordinate with various sectors and actors. People shall be aware about economic potentials in their immediate region, and to enforce these potentials would need financial aids from central and local government.

Implication of Result of Research:

The condition of resource factor and the condition of strategy and business competition among MSMEs in Great Malang are still affected by whether the government is supporting (or constraining) the development of targeted MSMEs because the strategies for developing the targeted MSMEs are only implementable through the support of government policies. The implication of result of research is that there are many aspects to be included into the design plan of One Tambon One Product model. It is said so because some organizations play important roles concerning with the development of MSMEs. These organizations include: the supporting organization for business development; the supporting organization for technical aids; and the coordination forum at district, regency/city, and province levels. The province level can also be served by cross-institution committee. All these organizations shall be meaningful for the successful initative to improve competitive advantage and market access of MSMEs in Great Malang to attain better development.

\section{REFERENCES}

Adirestuty, Fitranty, NidaAfifah and Ade Suyitno, 2011. Using OVOP Approach for Jacking Up Local Products by Empowering Local Association of College Students in the Campus Business Incubator, UPI Bandung.

Arsoowan Laeha, 2013. The Implementation of One Tambon One Product Policy to Increase People Participation in Natam District, Yala Province, Thailand. Public Administration Network. Fifth Edition. No.1, January-June. FISIP-UNAIR.

Helmsing, A.H.J., 2001. Local economic development: new generations of actors, policies and instruments. Draft paper for the Cape Town Symposium.

Astia, Dendi, 2004. Poverty Mitigation through MSME Empowerment: Some Lessons from Nusa Tenggara. Final Report of the Cooperation between Internal Affair Ministry, through its General Directorate of Local Development Fostering, and Deutsche Gesellschaftfür Technische Zusammernabeit (GTZ) $\mathrm{GmBH}$.

Blakely, J., Edward, 1998. Planning Local Economic Development: Theory and Practice, Sage Publications.

Bryman, A., 1988. Quantity and Quality in Social Research, Unwin Hyman, London.

Gunarianto, M., Nasri, 2011. Review on the Compilation of Competence of Local Industries in Pasuruan City. Result of Research.

Gunarianto, SitiAsiyah and Alfiana, 2008. Review on Capital Investment Flow into MSMEs in Sector of Trade \& Service in Blitar City. Faculty of Economic, Malang Widyagama University. Result of joint research in cooperation with the Government of Blitar City.

Gunarianto, TutiHastuti and SitiAsiyah, 2008. Review on Allocation Strategy of the 2008 APBD to Accelerate IPM Improvement and Poverty Mitigation in Belu Atambua Regency. Faculty of Economic, Malang Widyagama University. Result of joint research in cooperation with the Government of Atambua City.

Gunarianto, TutiHastuti and SitiAsiyah, 2007. The Formulation of Policy Concept to Improve Quality of Micro \& Small Industry Centers in Blitar City.

Faculty of Economic, Malang Widyagama University. Result of joint research in cooperation with the Government of Blitar City.

Gunarianto, A.T., Marjani, P.S. Endah, 2014. The Analysis of Earning Management and Earning Response Coefficient: Empirical Evidence From Manufacturing Companies Listed in Indonesian Stock Exchange. International Journal of Business and Management Invention, 3(8).

Gunarianto, A.T., Marjani and P.S. Endah, 2015. Effect of Good Corporate Governance, Motivated Behavior and Implementation of Accounting Information System on Real Behavior of Earnings Management (Study atGo Public Manufacturing Companies in Indonesian Stock Exchange). Australian Journal of Basic and Applied Sciences, 9(33): 337-345.

Gunarianto, 2016. Capital Structure and Related Problems at Financial Firms That List WithIndonesia Stock Exchange. AustralianJournalofBasicandAppliedSciences, 10(9):30-38.

Gunarianto, 2016. Effect of Good Corporate Governance, Motivated Behavior, Implementation of Accounting Information System and Real Earnings 
Management Behavior on Company Performance (Study at Go Public Manufacturing Companies in Indonesian Stock Exchange). Australian Journal of Basic and Applied Sciences, 10(15): 92-101.

Gunarianto, 2017. The Formulation of One Tambon One Product Concept as the Effort to Empower Micro, Small \& Medium Enterprises in Designing the Strategy to Improve Their Competitive Advantage and Market Access in Welcoming ASEAN Market in Great Malang. Australian Journal of Basic and Applied Sciences,11(15): 34-46.

KRI International Corp, 2004. Final Report of Study about the Capacity Building of MSE Clusters in Indonesia Republic. The Government of Indonesia Republic through the Coordinator Ministry for Economic Issue, delegating to Department of Industry and Trade, and also through the State Ministry for Cooperative and Small \& Medium Enterprises, in cooperation with Japan International Cooperation Agency. Final Report is given on March.

Maliza and Feser, 1999. Understanding Local Economic Development, Center for Urban Policy Research, New Jersey.

Modul of Participatory Local Social Development (PLSD) in Planner Version, PSKM-UNHAS-JICA Indonesia, 1-10 August 2005.

Mulyono, 2016. The Making of Finance Skimming Policy for Primary Industry Sector in MSME in East Java. Result of Research.

Mulyono, 2015. The Design of Competitive Fostering Model for MSME in Mojokerto City. Result of Research.

Neuman, W.L., 2009. Social Research Methods, Qualitative and Quantitative Approach, Ally and Bacon, Bosto Gesellschaft für Technische Zusammernabeit (GTZ). Local Economic Development, position paper (draft 2004): What Makes LED?

Nurcahyo, Rahmat, Farizal, EdwinSetiadi and Saparudin, 2012, "Determination and Development of Core Competencies for Bekasi Regency", Journal of Industrial Engineering, 13(1): 37-42.

11.

Pasaribu, M., Sahat, 2011."Rural Agroindustry Development through OneVillageOneProduct(OVOP) Approach,Agroeconomic Research Forum, 29(1): 1-

Ratmono, NediHendriand Yateno, 2016. OVOP Approach to Leading Product Development Program in Lampung Province Region. ISSNPrinted 19786573/ISSNOnline:2477 - 300X DERIVATIVE, 10-2.

Sajarwan, Akhmad, Muses Embang, Mofit Saptono, Abdul Mukti, ReviSumaryati, MerryLidia and PandriYani, 2009."Developmental Study on the Program of One Village One Productin Palangka Raya City", Research \& Development Bulletin, 1(01): 3-14.

Saputro, J.W., Putu Wuri Handayani, Achmad Nizar Hidayanto and Indra Budi, 2010. "Roadmap of Research on EnterpriseResource Planning(ERP) with Focus on Small-Medium Enterprises (UKM) in Indonesia", Journal of Information Systems, 6(2): 140-145.

Sri Hermuningsih, Dewi Kusumaand Wardani, 2012. OneVillageOneProduct (OVOP) Approach to the Developmental Program for Policies Concerning Local Leading Products of IKM and MSME. Jogja Forum for Business Economy. Yogyakarta, 41-59.

Sumodiningrat, 2004. The Setting of Poverty Mitigation Strategy. Article was presented at the Workshop of Experience Sharing across the Locals in Poverty Mitigation Effort. The workshop was held at Sanur Paradise Plaza Hotel, Denpasar, Bali on 2-4 July 2004. In cooperation with National Agency for Planning, World Bank, GTZ and DFID.

Triharini, Meirina, DwinitaLarasati and R.Susanto, 2012.“OneVillage One Product (OVOP) Approach for the Development of Local Handicraft Potentials: Case Study on Pottery Handicrafts in Plered District, Purwakarta Regency". ITBJ. Vis.Art\&Des, 6(1): 28-41.

Tuti Hastuti, Alfiana and Siti Asiyah, 2014. Micro, Small and Medium Enterprise (MSME) Empowerment Model as the Effort for Peverty Eradication in Malang Raya. International Journal of Business and Management Invention (IJBMI) 3-1. Result of Competitive Bequest Research (PHB) on First Year.

Tuti Hastuti, Alfiana and Siti Asiyah, 2015. Micro, Small and Medium Enterprise (MSME) Empowerment Model as the Effort for Peverty Eradication in Malang Raya. International Journal of Business and Management Invention (IJBMI) Volume 4- Issues 1-Version 1 (January-2015 Version). Result of Competitive Bequest Research (PHB) on Second Year.

TutiHastuti, Alfiana and SitiAsiyah, 2013. Micro, Small and Medium Enterprise (MSME) Empowerment Model as the Effort for Poverty Eradication in Great Malang..Result of Competitive Bequest Research (PHB). DP2M-DIKTI. 